community is making to ensure that is the case. As Nature reported in August (see Nature 476, 385; 2011), a study by the National Academy of Sciences on research universities, due out by the end of 2011, is expected to recommend ways in which institutions could share resources and be more thrifty. Leaders of the medical community, who have seen funding through the National Institutes of Health double between 1998 and 2003 but slow since, are also making informal preparations to downsize their enterprise or survive on a flat budget. That the US scientific community is taking its cue from lawmakers to streamline operations reflects well, and could help to counter the image painted by critics of scientists as elitist ivory-tower types in ill-deserved, comfortable jobs.

Second, lobbyists should stress how money spent on science contributes to education. This requires action from the scientists too, to make sure they take their teaching responsibilities seriously. There is increasing political scrutiny of this role, which too many faculty researchers still regard as an inconvenience.

In Texas, governor and Republican presidential hopeful Rick Perry has introduced a more business-orientated approach to education that could, this month, see nearly half the undergraduate physics programmes in the state penalized with probation or closure if not enough students are graduating.

In response, physics faculties have pointed out, correctly, that such a severe policy would bar entry to science to minorities and students in poor areas, from which enrolment in science subjects is regrettably low. Up to one-third of graduates with undergraduate physics degrees in the United States come from programmes that would not meet the Texas requirements - to graduate 25 students in 5 years (see Nature http://dx.doi.org/10.1038/news.2011.559; 2011). This

diversity should be protected, not whittled away.

But lobbyists should take note: Texas physicists have responded too, with pledges to refocus their teaching responsibilities to educate and graduate more students. And many research universities are working to reward good teaching by staff scientists with promotions.

Similarly, scientists across the United States are taking a more personal stake in the education of the nation's children, a particularly

faculty

researchers

still regard

teaching as an

inconvenience."
"Too many

important step given that anti-science rhetoric flourishes in an atmosphere of scientific illiteracy.

Programmes such as PhysTEC, a national network of institutions working to get physics graduates into school classrooms, and the UTeach Institute in Austin, Texas, which does the same for all scientific and mathematical fields, are working to address the paradox that, although bachelor's graduation rates in physics are at an all-time high across the United States, there is a shortage of well-qualified physics teachers in secondary schools. Lobbyists could and should highlight such programmes as examples of publicly funded scientists giving back to the public.

It is easy to be pessimistic and to assume that science investment will suffer with the economic and political fortunes of the United States, no matter what scientists do. But scientists, lobbyists and the wider research community must guard against such fatalism. The positive vibe generated by recent lobbying events in Washington DC and the fact that, historically, both US political parties have worked to protect science from cuts, is cause for optimism. The message simply needs a little fine-tuning.

\section{The PSA position}

\section{The US government must take a firm stance on} whether prostate-cancer screening is justified.

$\mathrm{P}$ olitics and science do not always see eye to eye, but politics and public health, especially in the United States, have an even rockier relationship. So when a respected panel of experts assessed the evidence for a controversial test for prostate cancer, and found US policy wanting, it would have known it was entering dangerous waters.

The US Preventive Services Task Force therefore deserves much kudos for its conclusion earlier this month that the prostate-specific antigen (PSA) test does more harm than good when used to screen healthy men for cancer.

Doctors in the United States routinely use the PSA test, not least because federal insurance provider Medicare pays for so many of them.

The task force's recommendation that the test should not be used in individuals with no symptoms, which is now open for public comment, has already been attacked by many doctors. The American Urological Association in Linthicum, Maryland, has started a campaign against the proposal, and newspapers have dedicated a large amount of space to letters from men stating that PSA tests saved their lives.

True, the data point in contrasting directions on the benefits of taking the test, given the unpleasant side effects of surgery - such as impotence and incontinence - to remove tumours that may not prove deadly. That is why the task force's conclusion is so important: the balance of the evidence, however inconvenient, shows that routine use of the test is a liability to public health.

"The common perception that PSA-based early detection of prostate cancer prolongs lives is not supported by the scientific evidence," says the task force. Instead, "there is moderate certainty that the harms of PSA-based screening for prostate cancer outweigh the benefits".

The recommendation builds on a more tentative finding from the same group in 2008, which said that the evidence did not support PSA screening in men aged 75 and older and that the picture was unclear for younger men.

The update has not come as a huge surprise to medical experts outside the United States. The PSA test has long been viewed with suspicion in Europe - where it is not nearly so widely used. Even the man who invented the test - Richard Ablin - wrote in the New York Times last year that his work had led to a "profit-driven public health disaster".

Unfortunately, the "common perception" is strong. The latest analysis will not directly change the way that prostate cancer is screened for in the United States. For one thing, the PSA tests funded by Medicare are protected by legislation. But change may be afoot. Last year, the American Cancer Society in Atlanta, Georgia, subtly modified its guidelines to cast more doubt on the usefulness of the test in screening healthy men.

If confirmed, the task force's recommendation will provide a renewed opportunity for evidence to be put at the heart of policy, however uncomfortable that might be in the short term.

Last time the task force issued a controversial recommendation - on breast-cancer screening in 2009 - health secretary Kathleen Sebelius effectively disowned the body. She has given no indication that this will happen this time round. The Department of Health and Human Services is waiting for the final recommendation before it weighs in. But when push comes to shove, the government must find the courage to act.

PSA testing is big business, and allegations that scrapping it will see men being left to die from cancer are corrosive. But the PSA debate must not be about the money. It should be about the health of millions of men and how to collect and judge the research that informs their care.
D NATURE.COM To comment online, click on Editorials at: go.nature.com/xhunqv
Those who argue against the decision should arm themselves with supporting data, not political attacks and anecdotes. And policy-makers must deliver firm support for the task force, or give good reasons why they choose not to. 